\title{
P2X7 receptors are a potential novel target for anti-glioma therapies
}

\author{
Mastura Monif ${ }^{1}$, Terence J O'Brien², Kate J Drummond ${ }^{3}$, Christopher A Reid ${ }^{4}$, Simon V Liubinas ${ }^{3}$ \\ and David A Williams ${ }^{1 *}$
}

\begin{abstract}
Background: Human gliomas pose significant morbidity and mortality to those afflicted by them, and currently there are no curative treatment modalities available for these highly invasive tumours.

Methods: With the approval from the human ethics committee, patients diagnosed with brain tumour (glioma) were recruited for this study. At the time of surgical resection, freshly resected tumour as well as 'peri-tumour' tissue were taken directly from theatre to the laboratory and were successfully cultured. Confocal fluorescence microscopy techniques and immunohistochemistry were used for characterization of human glioma cultures. Dye uptake experiments and confocal microscopy were utilized for P2X7 receptor (P2X7R) pore activity.
\end{abstract}

Results: We reveal human glioma cultures to contain microglia in close association with glioma (tumour) cells. Both glioma cells and microglia were found to express the purinergic, ATP sensing, P2X7R. P2X7R protein expression was increased in microglia derived from tumour when compared to 'peri-tumour' tissue. The pore capacity of P2X7R in tumour-associated microglia was functional, as evidenced by dye uptake experiments. Importantly, inhibition of P2X7R with the synthetic antagonist, brilliant blue G (BBG) resulted in a significant decrease in the number of glioma cells in culture.

Conclusions: P2X7R was found to be over-expressed in grade IV human gliomas and its pore capacity was functional. Antagonism of P2X7R with BBG resulted in a decrease in tumour cell number. This identifies P2X7R as a promising therapeutic target to combat human glioma proliferation.

Keywords: Microglia, P2X7, Glioma, Cancer, P2X7 pore

\section{Background}

Gliomas are the most common type of intrinsic brain tumour and a major cause of morbidity and mortality for those afflicted by these highly invasive tumours. The majority of adult gliomas are high-grade astrocytomas, comprising grade 3 anaplastic astrocytoma (AA) and grade 4 glioblastoma multiforme (GBM) [1]. In addition to tumour cells, gliomas contain microglia, which are known to contribute to the tumour mass [2]. Microglia are the immunocompetent cells of the central nervous system. Under normal conditions microglia assume a quiescent/ resting (ramified) phenotype, but in the setting of brain injury or neoplasia microglia become activated [2].

\footnotetext{
*Correspondence: davidaw@unimelb.edu.au

'Department of Physiology, The University of Melbourne, Melbourne, Victoria 3010, Australia

Full list of author information is available at the end of the article
}

Activated microglia are capable of releasing various immunomodulatory molecules that could alter the course of tumourogenesis [3]. The mechanisms controlling the transition from ramified to activated microglia are not fully understood. We have recently shown that the purinergic receptor, P2X7R, is involved in this transition [4].

The P2X7R is an ATP sensing receptor expressed in cells of haemopoeitic and immunological origin such as monocytes, macrophages, mast cells and microglia [5]. Increased P2X7R expression in microglia in the brain has been reported in the setting of Alzheimer's disease [6,7], multiple sclerosis [8], brain ischemia [9] and spinal cord injury [10]. Pharmacological blockade of P2X7R has been shown to be neuroprotective in an animal model of Alzheimer's disease [6], enhance recovery in animal models of spinal cord injury [10], and reduce neuroinflammation in an experimental model of autoimmune encephalomyelitis 
[11]. P2X7R over-expression is also reported in a number of cancers, including those of the breast [12], prostate [12], thyroid [13] pancreas [14], melanoma [15,16], chronic lymphocytic leukemia [17], human neuroblastoma [18], the rat C6 glioma model, and more recently human glioblastoma [19]. However, the role that P2X7R plays in the biology of brain neoplasms is unknown.

The P2X7R has dual ionic conductance states. Transient stimulation with agonist (most commonly ATP) opens a P2X7R channel permeable to small cations, whereas sustained agonist stimulation leads to a pore state permeable to moieties of up to $900 \mathrm{Da}[20,21]$. The P2X7R pore activity has been most commonly associated with consequent cell death, apoptosis or cytolysis [20-23]. Recently, we showed that in transfected rat primary hippocampal neuron glia mixed cultures over-expression of P2X7R was sufficient to induce microglial activation and proliferation [4]. The trophic effects observed were dependant on P2X7R pore activity (not channel), and there was no evidence of P2X7R-induced cell death.

Whether P2X7R has a similar action in the setting of human brain tumours is not known. Previous studies have raised questions about the fundamental biological role of P2X7R in the setting of cancer and cell trophism. To explain the over-expression of a purported 'cytolytic' receptor in settings of cell trophism, some have suggested that the receptor must therefore be 'non-functional' to allow trophism rather than cell death [24]. It has also been argued that in the setting of cancer/cell trophism P2X7R is fully functional (intact channel and pore conductance) and it indeed serves a homeostatic anti-tumour function designed to have pro-apoptotic effects to deal with the growing tumour burden [12]. In contrast some studies have shown no evidence of P2X7R-mediated apoptosis, and attribute the trophism/tumour growth to P2X7R function itself [18].

In this study, we reveal increased P2X7R protein expression in microglia cultured from human brain tumour versus 'peri-tumour' (region of macroscopically normal brain surrounding the frank tumour). Pore activity was evident in microglia, indicative of a normally functioning receptor. These observations are also highly supportive of a trophic rather than cell killing role for P2X7R pore. Importantly, total inhibition of P2X7R activity (channel and pore conductances) with brilliant blue G (BBG) reduced the number of tumour cells in culture. The results from this study identify P2X7R as a potential anti-tumour therapeutic target.

\section{Methods}

\section{Human tumour and peri-tumour cultures}

Protocols for obtaining and handling human brain tissue were reviewed and approved by the Human Research Ethics Committee of the Royal Melbourne Hospital,
Victoria, Australia. Written informed consent to study brain tumour/'peri-tumour' tissue excised during tumour surgery was obtained from patients prior to the operation. Tumour tissue was obtained during routine tumour resection/debulking, and where safe 'peri-tumour' was obtained during the same operation. The 'peri-tumour' tissue comprised macroscopically normal brain adjacent to the tumour, which required removal for surgical access. Tissue was received by direct explant from the operating room and placed into sterile containers. Immediately after, the samples were taken to the laboratory and in the laminar flow hood (PC2 laboratory), the tissue was finely chopped. The respective tumour and 'peri-tumour' pieces were placed in an enzyme solution containing Papain (200 units; Sigma Aldrich) for 35 minutes at $37^{\circ} \mathrm{C}$. The tissue was washed 3 times to remove all traces of papain, and the mixture was triturated to obtain a single cell suspension. The cells were plated into 12 well plates containing $18 \mathrm{~mm}$ Poly-D-lysine (Sigma) coated coverslips (SDR Clinical Technology) at a density of $1.8 \times 10^{5}$ cells/well. Cultures were maintained in Minimum Essential Medium (Gibco, Invitrogen) with the following supplements: $1 \mathrm{mM}$ glucose, Penicillin-Streptomycin (5000 units/ml), 10\% heat inactivated Fetal Bovine Serum (GIBCO, Invitrogen), MITO + ${ }^{\mathrm{T}}$ Serum Extender (Becton Dickinson), and $2 \mathrm{mM}$ L-glutamine (GIBCO, Invitrogen). Cells were cultured at $37^{\circ} \mathrm{C}$ in a humidified incubator of $5 \% \mathrm{CO}_{2} / 95 \% \mathrm{O}_{2}$. All cultures were from grade IV (histological criteria) gliomas as diagnosed post-hoc after the removal of the tumour.

\section{Immunohistochemistry}

Human tumour and 'peri-tumour' cultures were fixed in a solution of acetone and methanol $(1: 1)$, at $-20^{\circ} \mathrm{C}$. After fixation, the cells were washed once with phosphate-buffered saline (PBS), and non-specific protein binding sites were blocked with 2\% Bovine Serum Albumin (Sigma) for $45 \mathrm{mi}$ nutes at $37^{\circ} \mathrm{C}$. The following primary antibodies were used: rabbit anti-GFAP (glial fibrillary acidic protein) primary antibody (final dilution of 1:400; a kind gift from Professor Jennifer Berka (Department of Immunology, Monash University, Melbourne, Australia), isolectin GS-IB 4 from Griffonia simplicifolia, Alexa Fluor ${ }^{\circ} 594$ conjugate (final dilution of 1:100; Molecular Probes), goat anti P2X7R antibody (y-14; final dilution 1:100; Quantum Scientific). Primary antibodies were made up in PBS, with $1 \%$ Triton-X100 for permeabilization, and were incubated overnight at $4^{\circ} \mathrm{C}$. After three, 5 minute washes in PBS, the cells were incubated with the relevant secondary antibodies: Alexa Fluor 488 (final dilution: 1:200; Molecular Probes) or Texas $\operatorname{Red}^{\oplus} \mathrm{X}$ (final dilution: 1:200; Molecular Probes). All secondary antibodies were incubated overnight at $4^{\circ} \mathrm{C}$. After three, 5 minute washes in PBS, the samples were mounted with DAKO Fluorescent Mounting Medium. No staining was detected in 
the absence of primary or secondary antibodies. Some preparations were counter labelled with DAPI nuclear stain ( $5 \mu \mathrm{M}$; Molecular Probes).

\section{Confocal microscopy}

Human tumour and 'peri-tumour' cultures were viewed with a Zeiss LSM 510 META multiphoton/confocal microscope equipped with $488 \mathrm{~nm}$ argon, 543 and $633 \mathrm{~nm}$ Green and Red Helium/Neon and $800 \mathrm{~nm}$ Chameleon lasers. Images were acquired with a 40× IR-Achromat (N.A. 0.80), water immersion objective. For most experiments samples were simultaneously stained with two or three fluorescent probes, with dual or triple emission achieved through appropriately selected emission filters, or by defining emission ranges following prior acquisition of lambda emission profiles for each probe individually. Images were analyzed using MetaMorph (Universal Imaging Corporation ${ }^{\circ}$ ) software for assessment of cell number. For live cell imaging, the cells were bathed in HEPES buffer (mM: $\mathrm{NaCl} 135, \mathrm{KCl}$ 5, HEPES 10, Glucose 10, $\mathrm{CaCl}_{2} 1, \mathrm{MgCl}_{2} \mathrm{pH}$ : 7.4) at room temperature $\left(\sim 25^{\circ} \mathrm{C}\right)$.

\section{P2X7R pore assay}

We measured the degree of P2X7R pore activity inherent in the culture environment in the absence of any exogenous pharmacological stimulus (designated as a pore 'snap-shot' experiment). At 7 days post culturing, the cells were exposed to $5 \mu \mathrm{M}$ of YOPRO-1 (345 kD; Molecular Probes) nuclear dye for 30 minutes. The cultures were then immediately fixed, and mounted for confocal imaging to assess the presence of pores by measuring YOPRO-1 intensity of cell nuclei. To confirm that the response observed was P2X7R specific, some human glioma cultures were pre-exposed to oxidized ATP, a specific and irreversible antagonist of P2X7R [25]. Oxidized ATP $(250 \mu \mathrm{M})$ was applied 2.5 hours prior to YOPRO-1 application. Thereafter, the cells were washed once in PBS, then immediately fixed, and mounted for confocal imaging to assess the presence of pores by measuring ethidium $^{+}$intensity of cell nuclei.

\section{BBG experiments}

Prior data from animal studies have revealed that BBG administration protocols that resulted in average tissue concentrations of 9.94-43.59 $\mu \mathrm{M}$ BBG over 3 consecutive days were effective in reducing microglial activation and enhancing recovery after spinal cord injury in rats [26]. We used the more conservative BBG concentration of $7 \mu \mathrm{M}$ to treat human glioma cultures at day 3 and 5 post culturing. The cultures were left in the presence of the BBG until day 10 post culture. By day 3 tumour and 'peri-tumour' cultured cells settled down for adherence to poly-D-lysine coated coverslips, while day 5 was routinely chosen as the day to replenish the culture medium. Thereafter, the cultures were fixed with a solution of acetone:methanol (50:50), and processed for immunohistochemistry as described above.

\section{Results}

Morphological and cellular characteristics of human gliomas in culture

We were able to successfully grow human tumour ( $\mathrm{n}=10$ patients) and 'peri-tumour' cultures ( $\mathrm{n}=10$ patients). Figure 1 shows human glioma cultures after 7 days of culturing, and illustrates extensive arrays of tumour cells (GFAP positive) dispersed throughout the culture environment. Tumour cells were found to cluster/aggregate forming a densely packed arrangement (Figure 1A,C). Within each cluster there were highly pleomorphic cells with multiple nuclei (Figure 1A). This aggregative capacity was absent from cultures derived from 'peri-tumour' tissue $(\mathrm{n}=4)$ peri-tumour cultures).

Microglia infiltrated the clusters of tumour cells, with microglia and tumour cells being in very close proximity to one another (Figure 2). Whilst GFAP-positive tumour cells were concentrated in the periphery of the cell clusters, microglia were found at the core of the cluster (Figure 2).

\section{P2X7R is over-expressed in microglia found in human glioma cultures}

Cell in these clusters were also found to express P2X7R (Figure 3). The expression of P2X7R was noted in both tumour cells (Figure 3A,B) and microglia (Figure 3C,D). Microglia derived from tumour tissue showed higher levels of P2X7R protein expression than microglia derived from 'peri-tumour' tissue (Figure 4A). Conversely, tumour cells derived from the core of the glioma were found to have lower P2X7R expression than tumour cells from 'peri-tumour' tissue (Figure 4B).

\section{The pore capacity of $\mathrm{P} 2 \mathrm{X7R}$ is active in human glioma associated microglia}

The incorporation of YOPRO-1, a high molecular weight fluorescence dye, indicates the presence of active P2X7R pores in human glioma microglia (Figure 5). YOPRO-1 incorporation was inhibited by blocking P2X7R activity with a specific and irreversible antagonist, oxATP, confirming the response was P2X7R specific (Figure 5). A significantly higher level of YOPRO-1 was incorporated into the nuclei of the glioma microglia suggesting that pore activity may be having a similar pro-activation (trophic) role to that previously described in rat hippocampal microglia $[4,27]$.

\section{Inhibition of P2X7R activity was found to lead to a decrease in the number of tumour cells}

When glioma cultures were incubated with BBG (an antagonist of P2X7R) after 3 and 5 days in culture, there 
were significantly fewer microglia and a reduced number of glioma cells in culture by day 10 (Figure 6).

\section{Discussion}

Human brain tumours grown in culture comprise microglia that are dispersed throughout and within the core of the tumour cells. Here we showed that both microglia and tumour cells expressed P2X7R, with higher expression levels in microglia associated with the tumour when compared to the 'peri-tumour'. Importantly, P2X7R pore activity was evident in tumour-associated microglia. Inhibition of overall P2X7R function led to a decrease in tumour cell number, revealing $\mathrm{P} 2 \mathrm{X} 7 \mathrm{R}$ as a potential anti-tumour therapeutic candidate.

In the culture environment, human brain tumours were found to have a significant number of microglia in close association with the tumour cells. Microglia within astrocytomas are known to proliferate along the architecture formed by tumour cells [28]. In addition, astrocytoma cells produce the microglia and monocyte chemoattractant proten-1 (MCP-1) [29] with microglia expressing the MCP-1 receptor, CCR2 [30]. Hence, increased presence of microglia at the site of astrocytic glioma may result from recruitment of microglia, as well as local microglial proliferation. Interestingly, tumours with a higher proliferation rate such as GBM contain significantly higher numbers of activated microglia compared to tumours of lower grade [2]. Similarly, a positive correlation has been found between the number of CD11b-positive microglia/macrophages in gliomas and the proliferative capacity of the tumour as indexed by bromodeoxyuridine $(\mathrm{BrdU})^{+}$or $\mathrm{Ki}-$ $67^{+}$labelling [31]. The proliferative capacity of microglia within human brain tumours should therefore be taken into account when histologically characterizing tumour progression/invasion and potentially determining patient prognosis.

Interestingly, we found P2X7R expression to be enhanced in 'peri-tumour' glioma cells compared to tumourassociated glioma cells, suggesting that this may play a role actively invading glioma cells. Conversely, P2X7R expression was increased in tumour-associated microglia compared to microglia derived from the 'peri-tumour' brain. P2X7R up-regulation has been shown in many different cancer types, but the majority of these studies have not defined the locality (i.e., tumour or 'peri-tumour' region) of that expression. Whether P2X7R functions as a proapoptotic/cytolytic entity or conversely leads to tumour growth is also not fully understood. There are observations of enhanced P2X7R expression in solid epithelial tumours [12] and strong up-regulation of P2X7R in samples from thyroid cancer lines [32]. P2X7R up-regulation was also shown in thyroid papillary cancer, and the receptor was found to be fully functional [32], the authors suggesting P2X7R as a possible biomarker of the disease. In 


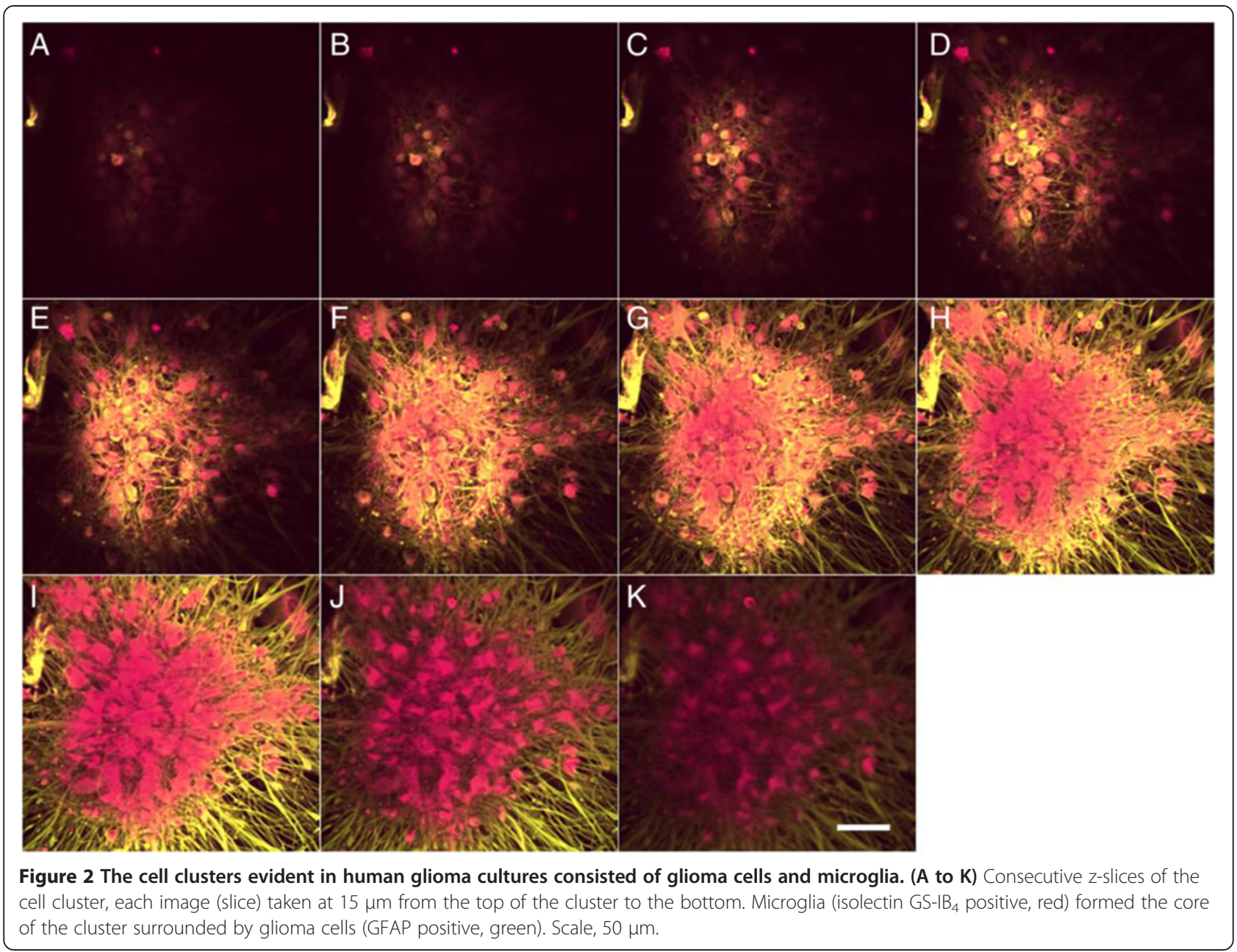

prostate cancer P2X7R expression was increased [33], and a monoclonal anti-P2X7R antibody is currently being designed for use as a prostate cancer biomarker. Similarly, in newly diagnosed pediatric acute leukemias P2X7R expression was increased, especially in cases of relapsed disease and the receptor was found to be fully functional [34]. In rat C6 glioma cells P2X7R mRNA and protein were upregulated upon exposure to P2X7R specific agonist BzATP, and the stimulation of P2X7R was linked to release of proinflammatory markers and tumour cell migration [35]. P2X7R stimulation with ATP was found to be important in maintenance of survival of Neuro-2a neuroblastoma cells [36]. In neuroblastoma cells, stimulation of P2X7R resulted in cell shrinkage and plasma membrane blebbing, with no signs of apoptosis or necrosis, but with evidence of proliferation [18]. Similarly, immunohistochemical data revealed increased P2X7R expression in Schwann cells from human lingual nerve neuromas [37] and in human gliomas [19]. In this latter study P2X7R expression in glioma tissue was compared with brain tissue from individuals with other neurological conditions. No distinction could be made between tumour and 'peri-tumour' tissue within the same individual and the specific cell contributions (microglia versus glioma cells) in the increased P2X7R expression was also not defined [19].

So while we have shown that microglia occur in close association to human brain tumour cells and that they have increased P2X7R expression, do microglia and P2X7R actually contribute to tumour growth/proliferation? In primary hippocampal cultures we have previously shown that P2X7R pore activity (not channel) drives microglial activation and proliferation as well as inducing the release of inflammatory mediators [4]. This finding was somewhat surprising given that this conductance state of the P2X7R was widely held to be cytolytic $[20,21,24,38-40]$ rather than trophic. Similarly, in B-cell chronic lymphocytic leukemia where P2X7R was shown to be over-expressed, the authors suggested that the receptor must be non-functional producing an antiapoptotic effect and leading to accumulation of tumour cells [24]. In C6 glioma cell line P2X7R suppression was also shown to cause cell proliferation with angiogenesis, 

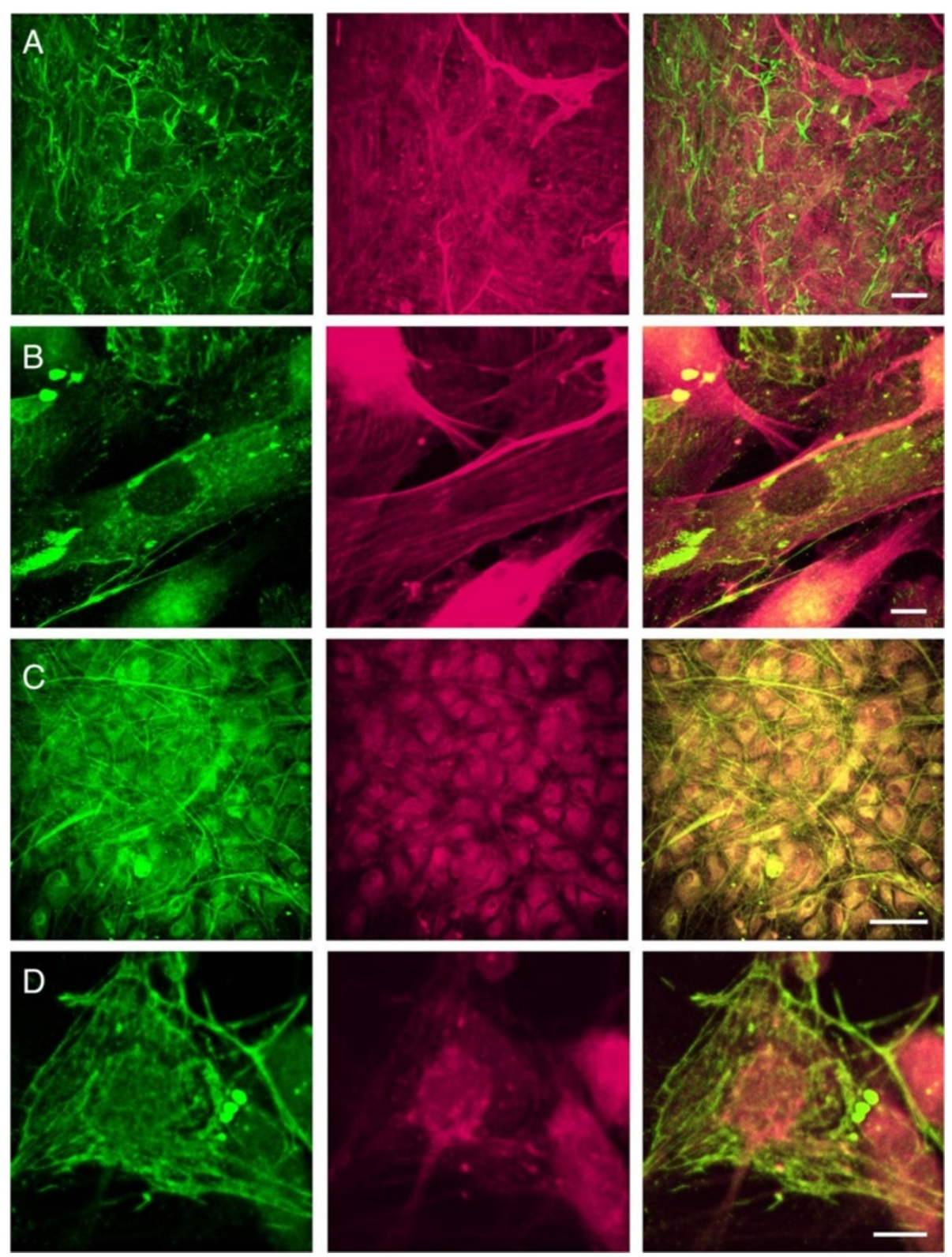

Figure 3 The human glioma cell clusters in culture were P2X7R positive. A: Cell cluster of glioma cells (GFAP positive, red) also expressed P2X7R receptor (green). Scale, $100 \mu \mathrm{m}$. B: Magnified image of a glioma cell (GFAP positive, red), also expressing P2X7R (green). Image in the right showing the co-localization of GFAP and immunoreactivity for P2X7R. Scale, $50 \mu \mathrm{m}$. C: Cell cluster in human glioma culture labeled for microglia (isolectin GS-IB 4 , red), also showed P2X7R immunoreactivity (green). Scale, $50 \mu \mathrm{m}$. D: Magnified image of a microglia (isolectin GS-IB 4 positive, red) showing expression of P2X7R (green). Right image shows co-localization of isolectin GS-IB 4 and P2X7R immunoreactivity. Scale, $10 \mu m$.

effects that were mediated by epidermal growth factor receptor [41]. Again, in this study no distinction was made between P2X7R pore versus channel activity. In contrast, we found glioma-associated microglia to have P2X7R pore, which was functional. Unlike the current dogma, it is possible that P2X7R pore has a trophic rather than apoptotic role in gliomas.

The current treatment options available for human high-grade astrocytoma include maximal safe surgical resection followed by radiotherapy with or without chemotherapy. However, although aggressive management can extend life, there is no cure and there remains a prognostic period of approximately six to twelve months especially for high-grade tumours [42]. The addition of targeted agents has received intense interest recently. The role of chemotherapy or radiotherapy alone remains limited $[43,44]$. Hence, more effective treatment modalities are needed. BBG is an 


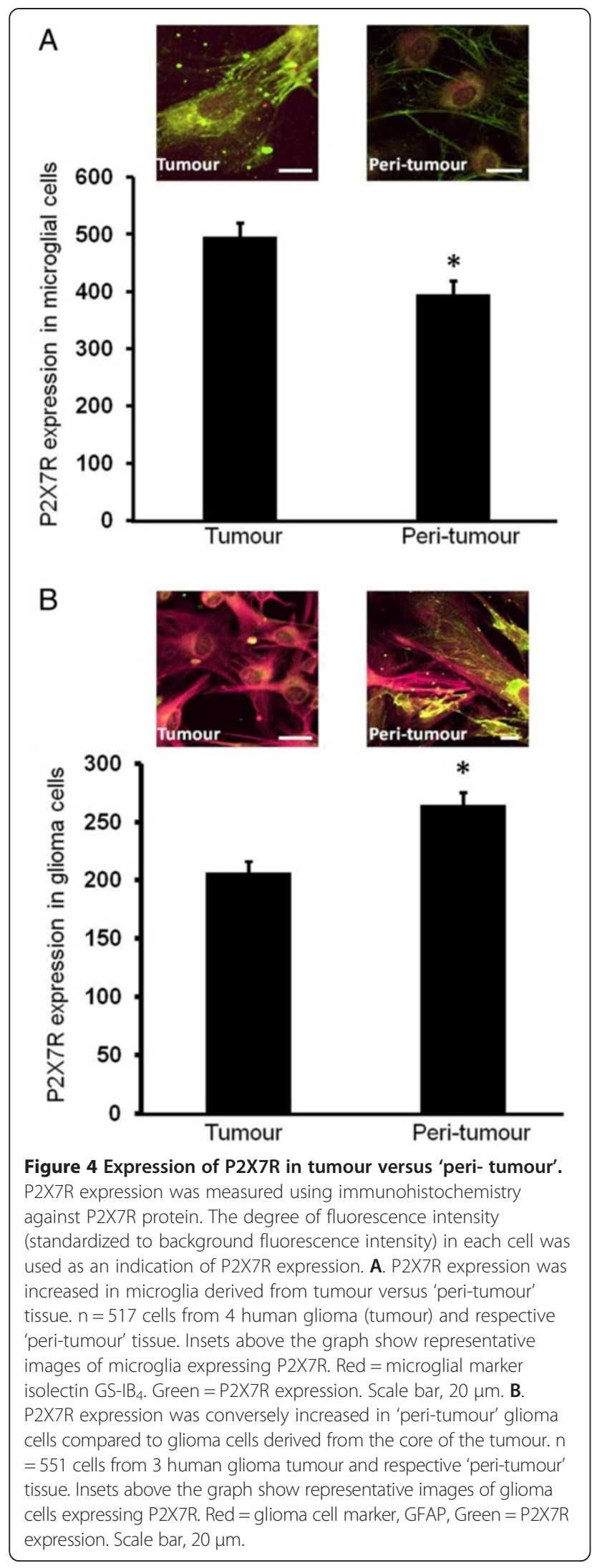

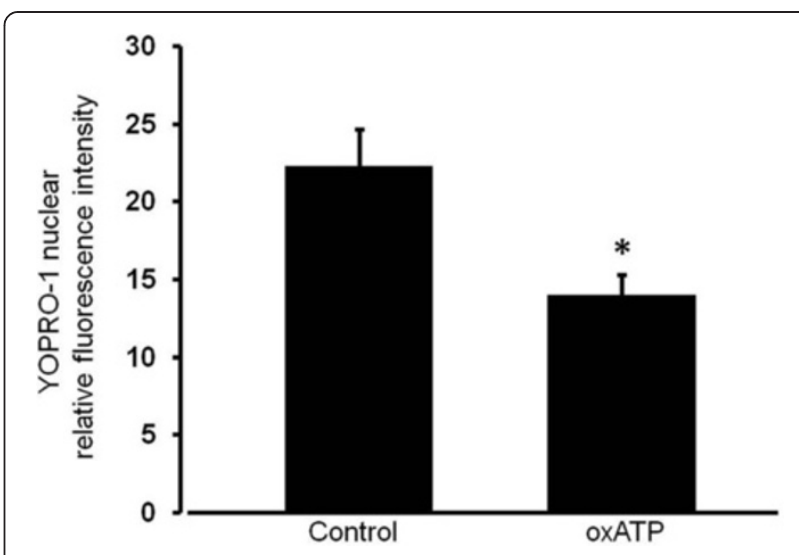

Figure 5 Microglia from human glioma at 3 days post culturing showed P2X7R pore activity, as evidenced by dye uptake experiments. YOPRO-1 nuclear intensity was measured as an index of P2X7R pore capacity ( $n=42$ microglia being isolectin GS-IB 4 positive from 3 human gliomas). This pore capacity was reduced with inhibition with a specific and irreversible antagonist of P2X7R, OXATP ( $250 \mu \mathrm{M}$ of OXATP for 3 hours prior to YOPRO-1 incubation, $n=28$ microglia, being isolectin $\mathrm{GS}-\mathrm{BB}_{4}$ positive from 3 human gliomas).

analogue of brilliant blue FCF (FD\&C blue dye No. 1) which is a synthetic dye approved by the Food and Drug Administration as a food additive considered as one of the safest dyes currently available, with no toxicity at doses of up to $12 \mathrm{mg} / \mathrm{kg}$ per day in healthy animals [45]. BBG is also a commonly used synthetic antagonist of P2X7R [46] with the capacity to penetrate the blood brain barrier [26]. In an animal model, average tissue concentrations of $9.94-43.49 \mu \mathrm{M}$ BBG administered reduced microglial activation and improved recovery after spinal cord injury [26]. No adverse effects on behaviour, weight, survival, or other physiological parameters, including body temperature, blood $\mathrm{pH}$, blood gases, or blood pressure were observed. On this basis, we used even a lower (presumably 'safer') dose of BBG $(7 \mu \mathrm{M})$ that was found to be effective in decreasing the number of microglia and glioma cells. It is possible that BBG acts either directly on P2X7Rs expressed on tumour cells, or indirectly via inhibiting P2X7Rs on tumour-associated microglia. We have shown over-expression of P2X7R alone to be sufficient in inducing microglial activation and proliferation [4]. Once activated, microglia are known to release factors such as vascular endothelial growth factor (VEGF) [47] and other cytokines (i.e., including IL6 and TNF- $\alpha$ ) involved in angiogenesis and tumour cell migration [48-50]. By driving microglial activation and proliferation with concomitant release of bioactive tumorigenic factors, it can be postulated that P2X7R plays a key role in the molecular hierarchy of glioma development. 

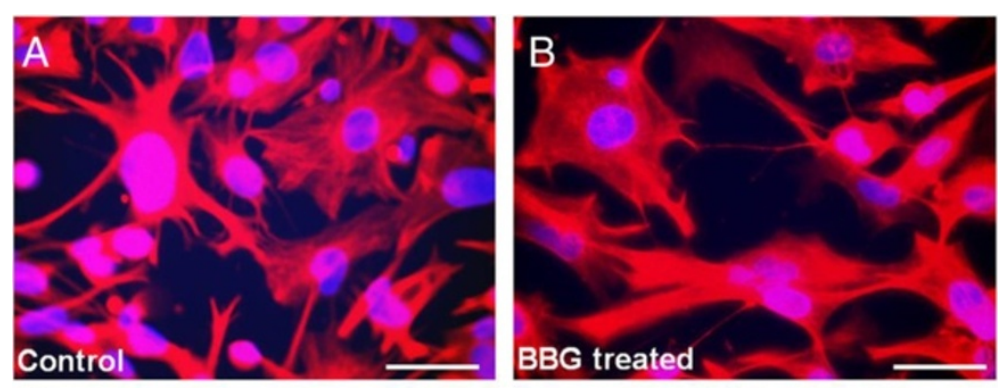

C

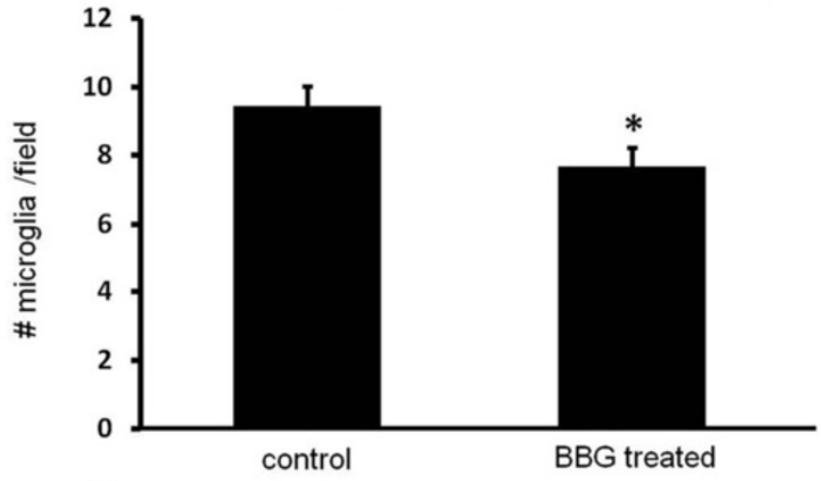

$\mathrm{D}$

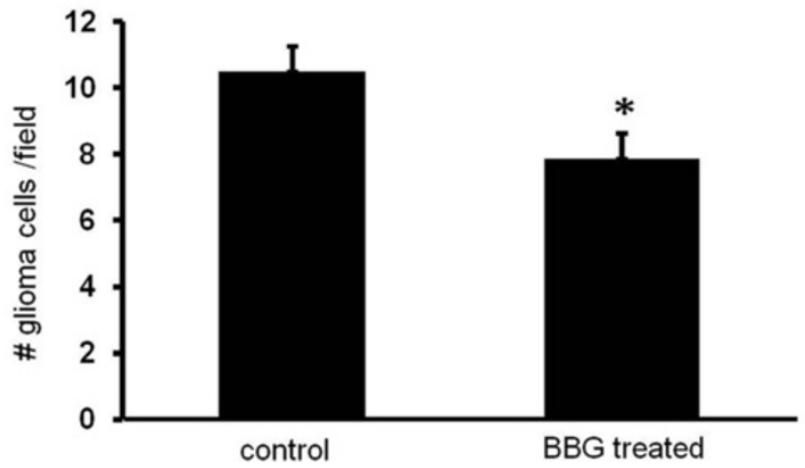

Figure 6 Inhibition of P2X7R with BBG reduced the number of glioma cells and microglia in human glioma cultures. Representative human glioma cell cultures before (A. control) and after (B. BBG) treatment with brilliant blue G. Red = isolectin GS IB4. Blue = DAPI nuclear stain. Scale bar, $20 \mu \mathrm{m}$. C. Treatment of human glioma cultures with $7 \mu \mathrm{M}$ BBG at day 3 and day 5 post culture reduced the number of microglial cells. The number of microglia were counted using immunohistochemistry against a microglial marker, isolectin GS IB4 at 10 days after culturing. Nuclei were counter labeled with DAPI nuclear stain. Cell numbers were counted using MetaMorph imaging software. $\mathrm{n}=109$ randomly selected fields from 3 human gliomas that were not treated with BBG (control). $n=107$ randomly selected fields from 3 human gliomas that were treated with BBG (BBG treated). D. Treatment of human glioma cultures with $7 \mu \mathrm{M} \mathrm{BBG}$ at day 3 and day 5 post culture reduced the number gliomas cells. The number of glioma cells were counted using immunohistochemistry against GFAP at 10 days after culturing. Nuclei were counter labeled with DAPI nuclear stain. Cell numbers were counted using MetaMorph imaging software. $n=114$ randomly selected fields from 7 human gliomas that were not treated with BBG (control). $n=113$ randomly selected fields from 7 human gliomas that were treated with BBG (BBG treated).

\section{Conclusions}

In conclusion, this study reveals human glioma cultures to show large numbers of microglia in close association with tumour cells. Both microglia and the tumour cells were found to express P2X7R whose expression was greater in tumour associated microglia versus 'peritumour' tissue. Importantly, P2X7R pore was active in these microglia, and inhibition of P2X7R function resulted in a decrease in the number of glioma cells. Overall, our data support P2X7R antagonism as a potential therapeutic avenue for treatment of human gliomas.

\section{Abbreviations}

AA: Anaplastic astrocytoma; GBM: Gliomblastoma multiforme; P2X7R: P2X7 receptor; BBG: Brilliant blue G; GFAP: Glial fibrillary acidic protein; VEGF: Vascular endothelial growth factor; MCP-1: Monocyte chemoattractant proten-1; TNF-a: Tumour necrosis factor alpha; IL-6: Interleukin 6; YOPRO: Carbocyanine nucleic acid stain.

\section{Competing interests}

The authors declare that they have no competing interests.

\section{Authors' contributions}

MM: conception and design, collection of tumours from theatre, culturing of tumours, immunohistochemistry, confocal microscopy, dye up-take experiments, results analysis, and drafting manuscript. TJO: conception and 
design of the study and interpretation of data. CAR: conception and design of experiments, interpretation of data, and editing of manuscript. KJD: neurosurgeon, acquisition of samples, conception and design of experiments. SVL: patient recruitment and consent. DAW: conception and design of experiments, analysis, interpretation of data, assisted with drafting, graphics and editing manuscript. All authors read and approved the final manuscript.

\section{Acknowledgements}

This study was supported in part by an NHMRC Project Grant (\#628301) to TOB and KD and an ARC Discovery Grant (DP0770955) to DAW.

\section{Author details}

'Department of Physiology, The University of Melbourne, Melbourne, Victoria 3010, Australia. ${ }^{2}$ Department of Medicine, Royal Melbourne Hospital, The University of Melbourne, Melbourne, Victoria 3010, Australia. ${ }^{3}$ Department of Surgery, Royal Melbourne Hospital, The University of Melbourne, Melbourne, Victoria 3010, Australia. ${ }^{4}$ Howard Florey Institute, The University of Melbourne, Melbourne, Victoria 3010, Australia.

Received: 15 November 2013 Accepted: 13 July 2014

Published: 28 August 2014

\section{References}

1. Kleihues P, Burger PC, Scheithauer BW: The new WHO classification of brain tumours. Brain Pathol 1993, 3:255-268.

2. Graeber MB, Scheithauer BW, Kreutzberg GW: Microglia in brain tumors. Glia 2002, 40:252-259.

3. Wesolowska A, Kwiatkowska A, Slomnicki L, Dembinski M, Master A, Sliwa M, Franciszkiewicz K, Chouaib S, Kaminska B: Microglia-derived TGF-beta as an important regulator of glioblastoma invasion-an inhibition of TGF-betadependent effects by shRNA against human TGF-beta type II receptor. Oncogene 2008, 27:918-930.

4. Monif M, Reid CA, Powell KL, Smart ML, Williams DA: The P2X7 receptor drives microglial activation and proliferation: a trophic role for P2X7R pore. J Neurosci 2009, 29:3781-3791.

5. Ralevic $\mathrm{V}$, Burnstock $\mathrm{G}$ : Receptors for purines and pyrimidines. Pharmacol Rev 1998, 50:413-492.

6. Parvathenani LK, Tertyshnikova S, Greco CR, Roberts SB, Robertson B, Posmantur R: P2X7 mediates superoxide production in primary microglia and is up-regulated in a transgenic mouse model of Alzheimer's disease. J Biol Chem 2003, 278:13309-13317.

7. Rye JA, O'Hara Tompkins N, Eck R, Neal WA: Promoting youth physical activity and healthy weight through schools. W V Med J 2008, 104:12-15.

8. Yiangou Y, Facer P, Durrenberger P, Chessell IP, Naylor A, Bountra C, Banati RR Anand P: COX-2, CB2 and P2X7-immunoreactivities are increased in activated microglial cells/macrophages of multiple sclerosis and amyotrophic lateral sclerosis spinal cord. BMC Neurol 2006, 6:12.

9. Franke H, Gunther A, Grosche J, Schmidt R, Rossner S, Reinhardt R, Faber-Zuschratter $H$, Schneider D, Illes P: P2X7 receptor expression after ischemia in the cerebral cortex of rats. J Neuropathol Exp Neurol 2004, 63:686-699.

10. Wang X, Arcuino G, Takano T, Lin J, Peng WG, Wan P, Li P, Xu Q, Liu QS, Goldman SA, Nedergaard M: P2X7 receptor inhibition improves recovery after spinal cord injury. Nat Med 2004, 10:821-827.

11. Matute C, Torre I, Perez-Cerda F, Pérez-Samartín A, Alberdi E, Etxebarria E, Arranz AM, Ravid R, Rodríguez-Antigüedad A, Sánchez-Gómez M, Domercq M: P2X(7) receptor blockade prevents ATP excitotoxicity in oligodendrocytes and ameliorates experimental autoimmune encephalomyelitis. J Neurosci 2007, 27:9525-9533.

12. Slater M, Danieletto S, Pooley M, Cheng Teh L, Gidley-Baird A, Barden JA: Differentiation between cancerous and normal hyperplastic lobules in breast lesions. Breast Cancer Res Treat 2004, 83:1-10.

13. Pines A, Bivi N, Vascotto C, Romanello M, D'Ambrosio C, Scaloni A, Damante G, Morisi R, Filetti S, Ferretti E, Quadrifoglio F, Tell G: Nucleotide receptors stimulation by extracellular ATP controls Hsp90 expression through APE1/ Ref-1 in thyroid cancer cells: a novel tumorigenic pathway. J Cell Physiol 2006, 209:44-55.

14. Kunzli BM, Berberat PO, Giese T, Csizmadia E, Kaczmarek E, Baker C, Halaceli I, Büchler MW, Friess H, Robson SC: Upregulation of CD39/NTPDases and P2 receptors in human pancreatic disease. Am J Physiol Gastrointest Liver Physiol 2007, 292:G223-G230.
15. Deli T, Varga N, Adam A, Kenessey I, Rásó E, Puskás LG, Tóvári J, Fodor J, Fehér M, Szigeti GP, Csernoch L, Tímár J: Functional genomics of calcium channels in human melanoma cells. Int J Cancer 2007, 121:55-65.

16. White $N$, Butler PE, Burnstock $G$ : Human melanomas express functional P2 X(7) receptors. Cell Tissue Res 2005, 321:411-418.

17. Adinolfi E, Melchiorri L, Falzoni S, Chiozzi P, Morelli A, Tieghi A, Cuneo A, Castoldi G, Di Virgilio F, Baricordi OR: P2X7 receptor expression in evolutive and indolent forms of chronic B lymphocytic leukemia. Blood 2002, 99:706-708.

18. Raffaghello L, Chiozzi P, Falzoni S, Di Virgilio F, Pistoia V: The P2X7 receptor sustains the growth of human neuroblastoma cells through a substance P-dependent mechanism. Cancer Res 2006, 66:907-914.

19. Ryu JK, Jantaratnotai N, Serrano-Perez MC, McGeer PL, McLarnon JG: Block of Purinergic P2X7R Inhibits Tumor Growth in a C6 Glioma Brain Tumor Animal Model. J Neuropathol Exp Neurol 2011, 70:13-22.

20. Di Virgilio F: The P2Z purinoceptor: an intriguing role in immunity, inflammation and cell death. Immunol Today 1995, 16:524-528.

21. Surprenant A, Rassendren F, Kawashima E, North RA, Buell G: The cytolytic P2Z receptor for extracellular ATP identified as a P2X receptor (P2X7). Science 1996, 272:735-738.

22. Schilling WP, Wasylyna T, Dubyak GR, Humphreys BD, Sinkins WG: Maitotoxin and P2Z/P2X(7) purinergic receptor stimulation activate a common cytolytic pore. Am J Physiol 1999, 277:C766-C776.

23. Wang $Q$, Wang L, Feng YH, Li X, Zeng R, Gorodeski Gl: P2X7 receptor-mediated apoptosis of human cervical epithelial cells. Am J Physiol Cell Physiol 2004, 287:C1349-C1358.

24. Wiley JS, Dao-Ung LP, Gu BJ, Sluyter R, Shemon AN, Li C, Taper J, Gallo J, Manoharan A: A loss-of-function polymorphic mutation in the cytolytic P2X7 receptor gene and chronic lymphocytic leukaemia: a molecular study. Lancet 2002, 359:1114-1119.

25. Murgia M, Hanau S, Pizzo P, Rippa M, Di Virgilio F, Oxidized ATP: An irreversible inhibitor of the macrophage purinergic P2Z receptor. J Biol Chem 1993, 268:8199-8203.

26. Peng W, Cotrina ML, Han X, Yu H, Bekar L, Blum L, Takano T, Tian GF, Goldman SA, Nedergaard M: Systemic administration of an antagonist of the ATP-sensitive receptor P2X7 improves recovery after spinal cord injury. Proc Natl Acad Sci U S A 2009, 106:12489-12493.

27. Monif $M$, Burnstock $G$, Williams DA: Microglia: proliferation and activation driven by the P2X7 receptor. Int I Biochem Cell Biol 2010, 42:1753-1756.

28. Klein R, Roggendorf W: Increased microglia proliferation separates pilocytic astrocytomas from diffuse astrocytomas: a double labeling study. Acta Neuropathol 2001, 101:245-248.

29. Prat E, Baron P, Meda L, Scarpini E, Galimberti D, Ardolino G, Catania A, Scarlato G: The human astrocytoma cell line U373MG produces monocyte chemotactic protein (MCP)-1 upon stimulation with beta-amyloid protein. Neurosci Lett 2000, 283:177-180.

30. Galasso JM, Stegman LD, Blaivas M, Harrison JK, Ross BD, Silverstein FS: Experimental gliosarcoma induces chemokine receptor expression in rat brain. Exp Neurol 2000, 161:85-95.

31. Morimura T, Neuchrist C, Kitz K, Budka H, Scheiner O, Kraft D, Lassmann H: Monocyte subpopulations in human gliomas: expression of $\mathrm{Fc}$ and complement receptors and correlation with tumor proliferation. Acta Neuropathol 1990, 80:287-294.

32. Solini A, Cuccato S, Ferrari D, Santini E, Gulinelli S, Callegari MG, Dardano A, Faviana P, Madec S, Di Virgilio F, Monzani F: Increased P2X7 receptor expression and function in thyroid papillary cancer: a new potential marker of the disease? Endocrinology 2008, 149:389-396.

33. Slater M, Danieletto S, Gidley-Baird A, Teh LC, Barden JA: Early prostate cancer detected using expression of non-functional cytolytic P2X7 receptors. Histopathology 2004, 44:206-215.

34. Chong JH, Zheng GG, Zhu XF, Guo Y, Wang L, Ma CH, Liu SY, Xu LL, Lin YM, Wu KF: Abnormal expression of P2X family receptors in Chinese pediatric acute leukemias. Biochem Biophys Res Commun 2010, 391:498-504.

35. Wei W, Ryu JK, Choi HB, McLarnon JG: Expression and function of the $\mathrm{P} 2 \mathrm{X}(7)$ receptor in rat C6 glioma cells. Cancer Lett 2008, 260:79-87.

36. Wu PY, Lin YC, Chang CL, Lu HT, Chin CH, Hsu TT, Chu D, Sun SH: Functional decreases in $\mathrm{P} 2 \mathrm{X} 7$ receptors are associated with retinoic acid-induced neuronal differentiation of Neuro-2a neuroblastoma cells. Cell Signal 2009, 21:881-891. 
37. Morgan CR, Bird EV, Robinson PP, Boissonade FM: Immunohistochemical analysis of the purinoceptor $\mathrm{P} 2 \mathrm{X7}$ in human lingual nerve neuromas. J Orofac Pain 2009, 23:65-72.

38. Nuttle LC, Dubyak GR: Differential activation of cation channels and non-selective pores by macrophage $\mathrm{P} 2 \mathrm{z}$ purinergic receptors expressed in Xenopus oocytes. J Biol Chem 1994, 269:13988-13996.

39. Pizzo P, Murgia M, Zambon A, Zanovello P, Bronte V, Pietrobon D, Di Virgilio F: Role of $\mathrm{P} 2 \mathrm{z}$ purinergic receptors in ATP-mediated killing of tumor necrosis factor (TNF)-sensitive and TNF-resistant L929 fibroblasts. J Immunol 1992, 149:3372-3378.

40. Rassendren F, Buell G, Newbolt A, North RA, Surprenant A: Identification of amino acid residues contributing to the pore of a P2X receptor. Embo J 1997, 16:3446-3454

41. Fang J, Chen X, Zhang L, Chen J, Liang Y, Li X, Xiang J, Wang L, Guo G, Zhang B, Zhang W: P2X7R suppression promotes glioma growth through epidermal growth factor receptor signal pathway. Int J Bioche Cell Biol 2013, 45(6):1109-1120.

42. Hayes RL, Koslow M, Hiesiger EM, Hymes KB, Hochster HS, Moore EJ, Pierz DM, Chen DK, Budzilovich GN, Ransohoff J: Improved long term survival after intracavitary interleukin-2 and lymphokine-activated killer cells for adults with recurrent malignant glioma. Cancer 1995, 76:840-852.

43. Cher L, Rosenthal MA, Drummond KJ, Dally M, Murphy M, Ashley D, Thursfield V, Giles GG: The use of chemotherapy in patients with gliomas: patterns of care in Victoria from 1998-2000. J Clin Neurosci 2008, 15:398-401.

44. Stupp R, Mason WP, van den Bent MJ, Weller M, Fisher B, Taphoorn MJ, Belanger K, Brandes AA, Marosi C, Bogdahn U, Curschmann J, Janzer RC, Ludwin SK, Gorlia T, Allgeier A, Lacombe D, Cairncross JG, Eisenhauer E, Mirimanoff RO, European Organisation for Research and Treatment of Cancer Brain Tumor and Radiotherapy Groups, National Cancer Institute of Canada Clinical Trials Group: Radiotherapy plus concomitant and adjuvant temozolomide for glioblastoma. N Engl J Med 2005, 352:987-996.

45. Borzelleca JF, Depukat K, Hallagan JB: Lifetime toxicity/carcinogenicity studies of FD \& C Blue No. 1 (brilliant blue FCF) in rats and mice. Food Chem Toxicol 1990, 28:221-234.

46. Jiang $L H$, Mackenzie $A B$, North RA, Surprenant A: Brilliant blue G selectively blocks ATP-gated rat P2X(7) receptors. Mol Pharmacol 2000, 58:82-88.

47. Lafuente JV, Adan B, Alkiza K, Garibi JM, Rossi M, Cruz-Sanchez FF: Expression of vascular endothelial growth factor (VEGF) and platelet-derived growth factor receptor-beta (PDGFR-beta) in human gliomas. J Mol Neurosci 1999, 13:177-185.

48. Palma C, Urbani F, Manzini S: Interleukin-6 production by U373 MG, a human astrocytoma cell line: different pathways involved in substance $P$ and lipopolysaccharide activation. J Neuroimmunol 1995, 59:155-163.

49. Luber-Narod J, Kage R, Leeman SE: Substance P enhances the secretion of tumor necrosis factor-alpha from neuroglial cells stimulated with lipopolysaccharide. J Immunol 1994, 152:819-824.

50. Sliwa M, Markovic D, Gabrusiewicz K, Synowitz M, Glass R, Zawadzka M, Wesolowska A, Kettenmann H, Kaminska B: The invasion promoting effect of microglia on glioblastoma cells is inhibited by cyclosporin A. Brain 2007, 130:476-489.

doi:10.1186/s12950-014-0025-4

Cite this article as: Monif et al:: P2X7 receptors are a potential novel target for anti-glioma therapies. Journal of Inflammation 2014 11:25.

\section{Submit your next manuscript to BioMed Central and take full advantage of:}

- Convenient online submission

- Thorough peer review

- No space constraints or color figure charges

- Immediate publication on acceptance

- Inclusion in PubMed, CAS, Scopus and Google Scholar

- Research which is freely available for redistribution 